\title{
PENERAPAN MODEL PEMBELAJARAN GROUP INVESTIGATION DALAM MENINGKATKAN HASIL BELAJAR MATEMATIKA SISWA
}

\author{
Irmawaty Natsir ${ }^{1 *}$, Abdul Rachman Taufik ${ }^{2}$ \\ ${ }^{1,2}$ Prodi Pendidikan Matematika Fakultas Keguruan dan Ilmu Pendidikan, Universitas Musamus Merauke \\ Jl. Kamizaun Mopah Lama, Rimba Jaya, Kec. Merauke, Kabupaten Merauke, Papua 99611, Indonesia \\ e-mail: ${ }^{1}$ natsir_fkip@unmus.ac.id; \\ corresponding author*
}

\begin{abstract}
Abstrak
Penelitian ini dilatarbelakangi beberapa masalah yang ditemukan di lapangan, diantaranya proses pembelajaran masih di dominasi oleh guru, kurangnya keikutsertaan siswa dalam kegiatan belajar secara aktif, kurangnya motivasi siswa dalam belajar, serta kurangnya kerjasama antar siswa. Penelitian ini dilaksanakan di salah satu SMP Negeri yang terletak di Kota Makassar, Indonesia tahun ajaran 2017/2018 yang bertujuan meningkatkan hasil belajar matematika siswa melalui penerapan model pembelajaran group investigation. Subjek penelitian adalah siswa kelas VIII dengan jumlah siswa 31 orang. Penelitian tindakan kelas ini terdiri dari 2 siklus, dimana setiap siklusnya terdiri dari 3 kali pertemuan dan 1 kali tes siklus. Informasi terkait aktivitas siswa dikumpulkan menggunakan lembar pengamatan dan informasi terkait kemampuan siswa dikumpulkan menggunakan tes yang diberikan setiap akhir siklus. Perolehan skor untuk siklus 1 adalah 70,48 dengan tingkat ketuntasan sebesar 70,79\% dan perolehan skor untuk siklus 2 adalah 76,32 dengan tingkat ketuntasan sebesar $87,1 \%$. Setelah diterapkan pembelajaran dengan tahapan group investigation menunjukkan adanya peningkatan aktivitas dan kemampuan siswa pada siklus 2 yang secara menyeluruh telah mencapai ketuntasan secara klasikal yakni $75 \%$.
\end{abstract}

Kata Kunci: hasil belajar, dan model pembelajaran group investigation

\section{APPLICATION OF GROUP INVESTIGATION TO IMPROVE STUDENTS LEARNING OUTCOMES IN MATHEMATICS}

\begin{abstract}
This research discusses several problems found in the field, studying the learning process that is still dominated by the teacher, avoiding student participation in active learning activities, increasing student motivation in learning, and increasing collaboration between students. This research was conducted in one of the State Junior High Schools located in Makassar City, Indonesia in the academic year 2017/2018 which aims to improve student learning outcomes through the application of investigative group learning models. The research subjects were students of class VIII with 31 students. This class action research consists of 2 cycles, where each cycle consists of 3 meetings and 1 cycle test. Information related to student activities is collected using observation sheets and information related to student abilities is collected using tests given at the end of the cycle. Obtaining a score for cycle 1 is 70.48 with a completeness level of $70.79 \%$ and a score for cycle 2 is 76.32 with a completeness level of $87.1 \%$. After applying learning with the investigation stage the group showed an increase in activity and the ability of students in the second cycle that was supported had reached classical completeness by $75 \%$.
\end{abstract}

Keywords: learning outcome, and learning model group investigation

Copyright ( $\odot$ Authors. This is an open access article distributed under the Attribution-NonCommercialShareAlike 4.0 International (CC BY-NC-SA 4.0), which permits unrestricted use, distribution, and reproduction in any medium, provided the original work is properly cited. 


\section{Pendahuluan}

Pendidikan menjadi standar pengukuran kehidupan setiap individu dimana perkembangan potensi setiap individu dapat difasilitasi melalui pendidikan secara menyeluruh. Pendidikan di Indonesia terus mengalami perkembangan setiap tahunnya. Ini terlihat dari upaya pemerintah dalam meningkatkan kualitas pendidikan seperti revisi kurikulum, proses pembelajaran baik metode, strategi maupun model yang digunakan, serta sarana dan prasarana.

Dengan adanya peningkatan kualitas pendidikan melalui pengembangan perangkat pembelajaran maka proses pembelajaran dapat dipersiapkan, dirancang agar menarik sehingga dapat menumbuhkan aktivitas siswa (Wanabuliandari, 2016) dan dapat menentukan keberhasilan serta ketercapaian suatu tujuan pembelajaran. Oleh sebab itu, sekolah sebagai lembaga pendidikan wajib melakukan pengembangan perangkat pembelajaran terkait dengan metode, model dan strategi yang digunakan.

Proses pendidikan yang berlangsung di sekolah, guru berperan dalam memotivasi dan mendorong siswa belajar untuk kreatif, inovatif dan menciptakan ide-ide dalam kegiatan pembelajaran melalui lingkungan belajar yang menyenangkan. Selain guru, keikutsertaan siswa dalam kegiatan belajar secara aktif dapat menggali pengetahuan dan kemampuan siswa sehingga terjadi perubahan pandangan terkait dengan proses belajar pada umumnya. Tetapi, berbagai permasalahan masih menjadi polemik bagi setiap lembaga pendidikan, diantaranya rendahnya hasil belajar siswa dalam mata pelajaran matematika. Sebagaimana yang diketahui bersama pelajaran matematika dapat meningkatkan kualitas siswa karena sifatnya yang abstrak menuntut siswa berpikir secara kritis, logis dan kreatif sehingga kemampuan siswa terlatih dalam menyelesaikan permasalahan yang diberikan (Natsir, 2019). Untuk itu, pembelajaran matematika wajib diajarkan mulai dari dasar hingga pendidikan tinggi kepada siswa pernyataan ini berdasar pada (Peraturan Menteri Pendidikan Nasional No. 22 Tahun 2006 tentang Standar Isi).

Dalam penerapannya, pembelajaran matematika belum mencapai taraf kualitas yang diharapkan, ini disebabkan kurangnya keikutsertaan siswa dalam kegiatan belajar secara aktif, kurangnya motivasi siswa dalam belajar, dan proses pembelajaran masih didominasi oleh guru serta kurangnya kerjasama antarsiswa. Untuk itu, dibutuhkan sebuah inovasi yang dapat memotivasi dan mengaktifkan siwa dalam belajar. Pembelajaran kooperatif menjadi satu diantara berbagai inovasi dalam mengaktifkan serta memotivasi siswa melalui proses gotong royong atau kerja kelompok.

Pembelajaran kooperatif menurut Johnson dan Johnson (dalam Isjoni, 2011) merupakan suatu kegiatan pembelajaran secara berkelompok dimana siswa secara bersama-sama belajar dan bekerjasama untuk mencapai pengalaman belajar. Strategi dalam pembelajaran kooperatif guru menjadi fasilitator dan melibatkan beberapa kelompok di dalam kelas sebagai subjek dalam pelaksanaan pembelajaran (Hamidi, 2007). Lebih lanjut, pembelajaran kooperatif dapat meningkatkan motivasi belajar siswa dimana siswa saling bergotong royong menyelesaikan masalah yang diberikan oleh guru, bertukar pendapat dan saling membantu jika ada siswa mengalami kesulitan.

Terdapat beberapa tipe dalam pembelajaran kooperatif dengan berbagai tahapannya. Group investigation menjadi satu diantara beberapa tipe dari pembelajaran kooperatif yang sangat kompleks dengan perpaduan beberapa landasan pemikiran dimana dalam prosesnya keterlibatan siswa mulai dari proses perencanaan hingga memahami suatu topik melalui investigasi, Budimansyah (Lanuihsan, dkk 2015).

$\begin{array}{lccc}\quad \text { Tahapan } & \text { dalam pembelajaran group } \\ \text { investigation } & \text { terdiri dari } & \text { identifikasi } \\ \text { masalah/topik, } & \text { perencanaan penyelidikan, }\end{array}$
pelaksanaan penyelidikan, penyiapan laporan dan evaluasi. Dalam pelaksanaan pembelajaran dengan tahapan GI siswa dibagi ke dalam kelompok tanpa membedakan kemampuan kognitif siswa yang terdiri 4-6 siswa. Selanjutnya, setiap kelompok dibagikan topik/ masalah untuk dipelajari kemudian siswa diminta untuk bekerja dalam kelompok membahas topik/ masalah tersebut. Dan, tahapan akhir guru mengecek pemahaman siswa terkait dengan topik/ masalah yang diberikan dengan melakukan evaluasi (Slavin, 2011). Pelaksanaan pembelajaran dengan penerapan model group investigation memberi kenyamanan siswa dimana suasana belajar menjadi menyenangkan dan menarik sehingga siswa aktif dan termotivasi dalam belajar serta segala aktivitas dalam proses belajar memberi pengalaman bagi siswa untuk mendapatkan sendiri informasi terkait dengan fakta atau konsep dari topik/masalah yang dipelajari sehingga pembelajaran lebih bermakna.

Beberapa hasil penelitian tentang penerapan model pembelajaran group investigation (GI) memiliki dampak positif diantaranya selain dapat 
meningkatkan hasil belajar siswa juga dapat menumbuhkan kemampuan berpikir, kerjasama dan mengembangkan sikap sosial siswa serta minat siswa (Suriati, E, 2018). Berdasarkan informasi yang diperoleh penulis, proses pembelajaran yang dilakukan belum optimal untuk dapat menumbuhkan keterampilan dan keaktifan siswa karena itu guru harus mampu membuat siswa tidak hanya mampu memahami konsep dan prinsip melainkan juga mengalami proses belajar dan memecahkan berbagai masalah melalui penerapan model pembelajaran group investigation (GI) sehingga dapat meningkatkan hasil belajar siswa.

\section{Metode Penelitian}

Pelaksanaan penelitian tindakan kelas ini dilaksanakan di salah satu SMP Negeri yang ada di kota Makassar, Indonesia tahun pelajaran 2017/2018 dan yang menjadi subjek penelitian adalah siswa kelas VIII dengan jumlah siswa 31 orang.

Data dikumpulkan menggunakan tes dan lembar observasi. Tes dipergunakan dalam mengukur sejauhmana pemahaman siswa tentang topik yang telah dipelajari pada kegiatan tatap muka. Tes yang diberikan dalam bentuk uraian sebanyak 10 nomor setiap siklusnya. Selanjutnya, untuk mengamati aktivitas siswa digunakan lembar observasi yang dijadikan sebagai pedoman dalam menentukan tindakan berikutnya.

Prosedur yang digunakan dalam penelitian ini yakni model yang dikembangkan oleh Kemmis \& Taggart (Wiriaatmadja, 2012). Tahapan model ini dimulai tahap persiapan, kemudian dilanjutkan tahap perencanaan dan pelaksanaan tindakan, tahap analisis yang terdiri dari observasi dan evaluasi, kemudian dilanjutkan dengan tahap refleksi dan tahap tindak lanjut. Hal yang dilakukan dalam tahap persiapan yakni melakukan observasi dan mengidentifikasi masalah-masalah yang ditemukan baik berasal dari siswa, guru maupun dalam proses pembelajaran yang kemudian dilanjutkan dengan pelaksanaan siklus penelitian.

\section{Adapun tahapan dari siklus ini yakni:}

a. Tahap perencanaan dalam siklus 1 yakni: pembuatan instrumen untuk digunakan pada tahapan selanjutnya seperti lembar observasi, tes dan RPP yang disesuaikan pada tahapan pembelajaran group investigation. Dan tahap perencanaan dalam siklus 2 dilakukan revisi terkait dengan model pembelajaran yang digunakan dan didasarkan pada hasil refleksi tahapan sebelumnya. b. Tahap pelaksanaan untuk siklus 1 dan 2 , pada tahap ini dilakukan kegiatan tatap muka sebanyak 3 kali dan pelaksanaan tes sebanyak 1 kali setiap siklus.

c. Tahap analisis, pada tahap ini meliputi observasi dan evaluasi. Observasi untuk siklus 1 dan 2 melakukan pengamatan dengan menggunakan lembar pengamatan yang telah disiapkan sebelumnya terkait dengan seluruh aktivitas yang dilakukan siswa selama proses belajar. Untuk tahap evaluasi siklus 1 dan 2 mengevaluasi seluruh proses yang dilakukan selama siklus 1 dan 2 yang dijadikan sebagai bahan dalam tahap refleksi.

d. Tahap refleksi, untuk siklus 1 dan 2 yang dilakukan dalam tahap ini yakni menganalisis kendala-kendala yang terdapat pada tahap evaluasi dan merencanakan tindakan-tindakan untuk megatasi kendala tersebut serta dilanjutkan dengan diskusi dalam menentukan pelaksanaan siklus lanjutan. Siklus lanjutan dilaksanakan apabila dalam proses pelaksanaan tujuan belum tercapai.

e. Tahap tindak lanjut, untuk siklus 1 dan siklus 2 yang dilakukan dalam tahapan ini yakni mengadakan diskusi dengan beberapa guru mata pelajaran matematika terkait dengan tindakan/langkah yang akan diambil dalam perbaikan dan pengembangan model pembelajaran sehingga hasil belajar siswa tercapai dengan optimal.

\section{Hasil dan Pembahasan}

Pelaksanaan tahapan penelitian ini melalui dua siklus dimana setiap siklusnya mengukur hasil tes dan kegiatan siswa selama pembelajaran dengan lembar pengamatan yang diuraikan berikut ini:

\subsection{Analisis Tes Siklus 1}

Penerapan model group investigation untuk siklus 1 diperoleh hasil analisis deskripsi skor perolehan siswa dan distribusi frekuensi pengelompokkan skor tes siswa sebagai berikut:

Tabel 1. Skor Tes Siklus 1

\begin{tabular}{ll}
\hline Statistik & Nilai statistik \\
\hline Subjek & 31 \\
Skor Ideal & 100 \\
Skor Maksimum & 88 \\
Skor Minimum & 45 \\
Rentang Skor & 43 \\
Skor Rata-Rata & 70,48 \\
\hline
\end{tabular}


Tabel 2. Distribusi Frekuensi Skor Tes Siklus 1

\begin{tabular}{clcc}
\hline Skor & \multicolumn{1}{c}{ K } & F & P (\%) \\
\hline $0 \leq \mathrm{x} \leq 54$ & Sangat rendah & 3 & 9,7 \\
$54<\mathrm{x} \leq 64$ & Rendah & 6 & 19,4 \\
$64<\mathrm{x} \leq 79$ & Sedang & 12 & 38,7 \\
$79<\mathrm{x} \leq 89$ & Tinggi & 10 & 32,2 \\
$89<\mathrm{x} \leq 100$ & Sangat tinggi & 0 & 0 \\
\hline
\end{tabular}

Berdasarkan tabel di atas diperoleh skor tes siswa untuk siklus 1 dengan skor rata-rata 70,48 dari 31 siswa, 3 diantaranya yang hasil belajarnya berada pada kategori sangat rendah, 6 diantaranya dengan kategori rendah, 12 diantaranya dengan kategori sedang, 10 diantaranya dengan kategori tinggi dan tidak terdapat yang hasil belajaranya berada pada kategori sangat tinggi. Tabel berikut menunjukkan hasil tes ketuntasan siswa untuk siklus 1 .

Tabel 3. Nilai Ketuntasan Siklus 1

\begin{tabular}{cccc}
\hline \multicolumn{1}{c}{ Skor } & $\mathbf{F}$ & $\mathbf{P}(\boldsymbol{\%})$ & $\mathbf{K}$ \\
\hline $0 \leq \mathrm{x}<65$ & 9 & 29,03 & Tidak Tuntas \\
$65 \leq \mathrm{x} \leq 100$ & 22 & 70,97 & Tuntas \\
\hline
\end{tabular}

Dari tabel di atas diperoleh hasil tes ketuntasan dari 31 siswa, 22 dinyatakan tuntas dengan tingkat ketuntasan 70,9\% dan 9 diantaranya dinyatakan tidak tuntas dengan tingkat ketuntasan hanya mencapai 29,03\%. Berdasarkan hasil ketuntasan yang diperoleh pada siklus 1 maka hasil belajar siswa dikatakan belum tuntas karena belum mencapai ketuntasan secara klasikal yakni $75 \%$. Untuk itu, perlu dilakukan tindakan lanjutan pada siklus berikutnya.

\subsection{Analisis Tes Siklus 2}

Penerapan model group investigation untuk siklus 2 diperoleh hasil analisis deskripsi skor perolehan siswa dan distribusi frekuensi pengelompokkan skor tes siswa sebagai berikut:

Tabel 4. Skor Tes Siklus 2

\begin{tabular}{ll}
\hline Statistik & Nilai statistik \\
\hline Subjek & 31 \\
Skor Ideal & 100 \\
Skor Maksimum & 100 \\
Skor Minimum & 55 \\
Rentang Skor & 45 \\
Skor Rata-Rata & 76,32 \\
\hline
\end{tabular}

Tabel 5. Distribusi Frekuensi Skor Tes Siklus 1

\begin{tabular}{rlcc}
\hline Skor & \multicolumn{1}{c}{ K } & F & P (\%) \\
\hline $0 \leq \mathrm{x} \leq 54$ & Sangat rendah & 4 & 12,9 \\
$54<\mathrm{x} \leq 64$ & Rendah & 0 & 0 \\
$64<\mathrm{x} \leq 79$ & Sedang & 12 & 38,7 \\
$79<\mathrm{x} \leq 89$ & Tinggi & 11 & 35,5 \\
$89<\mathrm{x} \leq 100$ & Sangat tinggi & 4 & 12,9 \\
\hline
\end{tabular}

Berdasarkan tabel di atas diperoleh hasil tes untuk siklus 2 dengan skor rata-rata 76,32 dari 31 siswa, 4 diantaranya yang hasil belajarnya berada pada kategori sangat rendah, jumlah ini bertambah 1 dari siklus sebelumnya, tidak terdapat yang hasil belajarnya berada pada kategori rendah, 12 diantaranya dengan kategori sedang, 11 diantaranya dengan kategori tinggi serta 4 diantaranya yang hasil belajarnya berada pada kategori sangat tinggi.

Tabel berikut menunjukkan hasil tes ketuntasan siswa untuk siklus 2 .

Tabel 6. Nilai Ketuntasan Siklus 2

\begin{tabular}{cccc}
\hline \multicolumn{1}{c}{ Skor } & $\mathbf{F}$ & $\mathbf{P}(\boldsymbol{\%})$ & $\mathbf{K}$ \\
\hline $0 \leq \mathrm{x}<65$ & 4 & 12,9 & Tidak Tuntas \\
$65 \leq \mathrm{x} \leq 100$ & 27 & 87,1 & Tuntas \\
\hline
\end{tabular}

Dari tabel di atas diperoleh hasil tes ketuntasan dari 31 siswa, 27 dinyatakan tuntas dengan tingkat ketuntasan 87,1\% dan 4 diantaranya dinyatakan tidak tuntas dengan tingkat ketuntasan hanya mencapai 12,9\%. Berdasarkan hasil ketuntasan yang diperoleh pada siklus 2 maka hasil belajar siswa dikatakan tuntas karena sudah mencapai ketuntasan klasikal sehingga tidak diperlukan tindakan lanjutan pada siklus berikutnya dikarenakan tujuan dari penelitian sudah tercapai. Untuk ketuntasan belajar siswa pada akhir siklus 1 dan 2 telah memenuhi ketuntasan secara klasikal yakni $75 \%$. Hal ini sejalan dengan hasil penelitian (Suriati, E, 2018) yakni tingkat ketuntasan siswa meningkat pada siklus I dan II dengan tingkat ketuntasan sebesar 93,33. Lebih lanjut, penelitian (Ayuwanti, I, 2016) juga memperoleh hasil yang sama yakni tingkat ketuntasan siswa meningkat pada siklus I, II dan III dengan tingkat ketuntasan pada siklus I ke siklus II sebesar $27,04 \%$ dan tingkat ketutasan pada pada siklus II ke siklus II sebesar 27,27\%.

\subsection{Analisis Lembar Observasi}

Tabel berikut menunjukkan hasil pengamatan kegiatan siswa selama proses belajar berlangsung.

Tabel 7. Pengamatan Aktivitas Siswa Untuk Siklus 1 dan Siklus 2

\begin{tabular}{lcc}
\hline Komponen yang diamati & \multicolumn{2}{c}{ P (\%) } \\
\cline { 2 - 3 } & Siklus 1 & Siklus 2 \\
\hline $\begin{array}{l}\text { Kehadiran siswa saat proses } \\
\text { belajar }\end{array}$ & 87,09 & 98,92 \\
\hline $\begin{array}{l}\text { Siswa yang fokus mengamati } \\
\text { penjelasan guru }\end{array}$ & 68,81 & 82,79 \\
\hline $\begin{array}{l}\text { Kemampuan siswa mengajukan } \\
\text { pertanyaan kepada guru pada } \\
\text { saat pembelajaran }\end{array}$ & 18,28 & 34,41 \\
\hline
\end{tabular}




\begin{tabular}{llc}
\hline $\begin{array}{l}\text { Keaktifan siswa dalam kegiatan } \\
\text { kelompok }\end{array}$ & 32,25 & 40,86 \\
\hline $\begin{array}{l}\text { Siswa yang meminta bimbingan } \\
\text { saat kerja kelompok kepada } \\
\text { guru }\end{array}$ & 27,96 & 15,05 \\
\hline $\begin{array}{l}\text { Keaktifan siswa memberi } \\
\text { tanggapan terhadap presentasi }\end{array}$ & 11,83 & 16,12 \\
kelompok & & \\
\hline $\begin{array}{l}\text { Kemampuan siswa menjawab } \\
\text { pertanyaan dari guru maupun } \\
\text { dari siswa }\end{array}$ & 9,68 & 10,75 \\
\hline $\begin{array}{l}\text { Siswa yang melakukan aktivitas } \\
\text { lain seperti ribut, bermain dsb }\end{array}$ & 17,20 & 8,60 \\
\hline
\end{tabular}

Berdasarkan tabel di atas terlihat adanya peningkatan dan penurunan persentase aktivitas siswa. Beberapa aktivitas siswa yang meningkat diantaranya kehadiran siswa saat proses belajar dengan persentase peningkatan sebesar $11,83 \%$, siswa yang fokus mengamati penjelasan guru juga mengalami peningkatan sebesar 13,98\%, begitupun dengan kemampuan siswa dalam mengajukan pertanyaan pada guru ikut pula mengalami peningkatan sebesar $16,13 \%$, kemampuan siswa menjawab pertanyaan juga mengalami peningkatan walaupun peningkatannya hanya sekitar $1,07 \%$ dari siklus 1 ke siklus 2 dan keaktifan siswa dalam kegiatan kelompok maupun memberi tanggapan terhadap presentasi kelompok juga mengalami peningkatan dengan persentase secara berturut-turut sebesar $8,61 \%$ dan $4,29 \%$. Lebih lanjut, aktivitas siswa yang mengalami penurunan yakni siswa yang meminta bimbingan saat kerja kelompok dan siswa yang melakukan aktivitas lain dengan persentase penurunan secara berturut-turut sebesar $12,91 \%$ dan $8,6 \%$. Ini sejalan dengan penelitian (Ayuwanti, I, 2016) adanya peningkatan aktivitas-aktivitas pada siklus I, II dan III Begitupula dengan penelitian (Suriati, E, 2018) yakni siswa lebih aktif selama proses pembelajaran.

\section{Kesimpulan}

Setelah penerapan pembelajaran dengan model group investigation di kelas VIII11 SMPN 25 Makassar mengalami peningkatan pada siklus 2 terlihat dari peningkatan skor yang diperoleh siswa pada siklus 1 yakni 70,48 menjadi 76,32 pada siklus 2 dan 27 siswa dinyatakan tuntas pada siklus 2 dimana pada siklus 1 hanya mencapai 22 yang tuntas, ini berarti ada penambahan siswa yang tuntas sekitar 5 siswa dengan tingkat ketuntasan sebesar $87,1 \%$ sehingga dapat disimpulkan hasil belajar siswa tuntas secara klasikal. Selanjutnya, hasil pengamatan aktivitas siswa diperoleh adanya peningkatan dan penurunan persentase aktivitas siswa. Beberapa aktivitas siswa yang meningkat diantaranya kehadiran siswa saat proses belajar dengan persentase peningkatan sebesar $11,83 \%$, siswa yang fokus mengamati penjelasan guru juga mengalami peningkatan sebesar $13,98 \%$, begitpun dengan kemampuan siswa dalam mengajukan pertanyaan pada guru ikut pula mengalami peningkatan sebesar $16,13 \%$, kemampuan siswa menjawab pertanyaan juga mengalami peningkatan walaupun peningkatannya hanya sekitar 1,07\% dari siklus 1 ke siklus 2 dan keaktifan siswa dalam kegiatan kelompok maupun memberi tanggapan terhadap presentasi kelompok juga mengalami peningkatan dengan persentase secara berturut-turut sebesar $8,61 \%$ dan $4,29 \%$. Lebih lanjut, aktivitas siswa yang mengalami penurunan yakni siswa yang meminta bimbingan saat kerja kelompok dan siswa yang melakukan aktivitas lain dengan persentase penurunan secara berturut-turut sebesar $12,91 \%$ dan $8,6 \%$.

\section{Daftar Pustaka}

Hamidi. (2007). Metode Penelitian dan Komunikasi. Malang: UPT Universitas Muhammadiyah Malang.

Ayuwanti, I.(2016). Meningkatkan Aktivitas dan Hasil Belajar Matematika Menggunakan Model Pembelajaran Kooperatif Tipe Group Investigation di SMK Tuma'ninah Yasin Metro, Jurnal SAP 1(2).

Isjoni. (2011). Pembelajaran Kooperatif Meningkatkan Kecerdasan Komunikasi Antar Peserta Didik. Yogyakarta: Pustaka Pelajar.

Lanuihsan,dkk. (2015). Peningkatan Prestasi Belajar dengan Menggunakan Model Pembelajaran Group Investigation (GI) pada Mata Pelajaran Kompetensi Kejuruan Kelas X SMK Negeri 3 Takalar. Jurnal Pendidikan Teknologi Pertanian, 1(1) 56-62.

Natsir, I. (2019). Pengaruh Intelegensi Interpersonal terhadap Intelegensi Emosional dan Kaitannya dengan Hasil Belajar Matematika. Musamus Jurnal of Mathematics Education, 2(1)50-58.

Depdiknas. (2006). Peraturan Menteri Pendidikan Nasional No. 22 Tahun 2006 tentang Standar Isi.Jakarta: Depdiknas.

Slavin, R. (2011). Cooperative Learning: Teori, Riset dan Praktik. Bandung: Nusa Media.

Suriati, E. (2018). Penerapan Model Pembelajaran Kooperatif Group Investigation (GI) untuk Meningkatkan Hasil Belajar Matematika Siswa pada Materi Trigonometri di Kelas X2 SMA Negeri 4 Wira Bangsa Meulaboh. Jurnal Ilmiah Pendidikan Matematika, 5(2) 98-108.

Wanabuliandari, S. (2016). Peningkatan Disposisi Matematis dengan pengembangan Perangkat Pembelajaran Matematika dengan Model Thinking Aloud Pairs Problem Solving (TAPPS) 
berbasis Multimedia. Refleksi Edukatika, 6(2),138-144

Wiriaatmadja, R. (2012). Metode Penelitian Tindakan Kelas. Bandung: PT Remaja Rosdakarya. 